American Journal of Environmental Sciences 6 (2): 137-151, 2010

ISSN 1553-345X

(C) 2010 Science Publications

\title{
The Importance of Maintaining a Proper Database on Forest Restoration Program for Orangutans in Borneo
}

\author{
${ }^{1}$ Raymond Alfred, ${ }^{1}$ Koh Pei Hue, ${ }^{1}$ Lee Shan Khee and ${ }^{2}$ Rayner Alfred \\ ${ }^{1}$ Borneo Species Programme, WWF-Malaysia1-6-W11, 6th Floor, CPS Tower, \\ Centre Point Complex, Jalan Centre Point, 80000 Kota Kinabalu, Sabah, Malaysia \\ ${ }^{2}$ School of Engineering and Information Technology, University Malaysia Sabah, \\ Locked Bag 2073, 88999 Kota Kinabalu, Sabah, Malaysia
}

\begin{abstract}
Problem statement: The lowland forest of Sabah is the most important habitat for orangutans and pygmy elephants. This is shown in the WWF-Malaysia's elephant tracking programme in which satellite-based Global Position System (GPS) collar devices are used to monitor their movement and the range of their habitats, as well as an aerial survey on orangutan's nest is performed to determine the spatial distribution pattern. We observed the activities of both species and we found that these species stay inside lowland forests with on flat ground or with gentle slopes, below $500 \mathrm{~m}$ elevation, which is mostly covered by natural forest. The density of orangutan's population was estimated to be higher in a certain location in natural lowland forests where the soils are more fertile. A suitable long term habitat for both species is located in the lowland dipterocarp forests. However, most of the pristine habitats in the lowland area have been converted into other land use activities such as a large scale plantation. This is due to the fact that most of the lowland forests are facing a continuous degradation process that will decrease its commercial value when it comes to generating revenue to the state government. As a result, the efforts to restore the forest are very vital. Approach: This study described the technical and biological aspects in the forest restoration planning, prioritizing, implementation and monitoring process, integrated with the data on habitat utilization by orangutan in lowland degraded dipterocarp forest. Key habitats for orangutans were identified, forest condition were mapped and field works are carried out using a plot sampling technique to identify the diversity and density of the forest (current and potential), in order to support the forest restoration planning. A proper database on forest restoration and tree maintenance planning had been developed to enable the monitoring process. Results: This study outlined some of the findings that include the main challenges that were faced in the forest restoration programme in North Ulu Segama (NUS), which could be used as lessons and guideline in the future. Conclusion: A long term monitoring programme is important in order to have a successful forest restoration programme as well as to have the opportunity to study the impact of this restoration on the behavior of orangutan as a result of their adaptation to the new forest structure.
\end{abstract}

Key words: Database for forest restoration, orangutans, forest quality assessment

\section{INTRODUCTION}

Timber and palm oil plantation industries in Sabah are the two main factors that contribute to the urgent needs of forest restoration programme.

In the past, the timber industry in Sabah was the main economic backbone of the socio-economic development of the state. In the year 2006, the forestry sector contributed about RM505.2 million (approximately $22.3 \%$ ) to the State's total revenue (SFD). However, Fig. 1 illustrates that the trend of the revenue contributed from the forestry industry shows declination from 1997-2002. In other words, the availability of timber (diameter at the breast height (dbh) with more than $60 \mathrm{~cm}$ ) during that time is not adequate or the stock is running low. However, when commercial timbers with bigger dbh (more than $60 \mathrm{~cm}$ of $\mathrm{dbh}$ ) became very limited, the government (Sabah Forestry Department) agreed to allow all commercial timbers that are below $30 \mathrm{~cm}$ dbh to be logged, within year 2002-2003. Revenue from the timber industry had increased again from 2003 for several years and it is

Corresponding Author: Raymond Alfred, Borneo Species Programme, WWF-Malaysia1-6-W11, 6th Floor, CPS Tower, Centre Point Complex, Jalan Centre Point, 80000 Kota Kinabalu, Sabah, Malaysia 
Am. J. Environ. Sci., 6 (2): 137-151, 2010

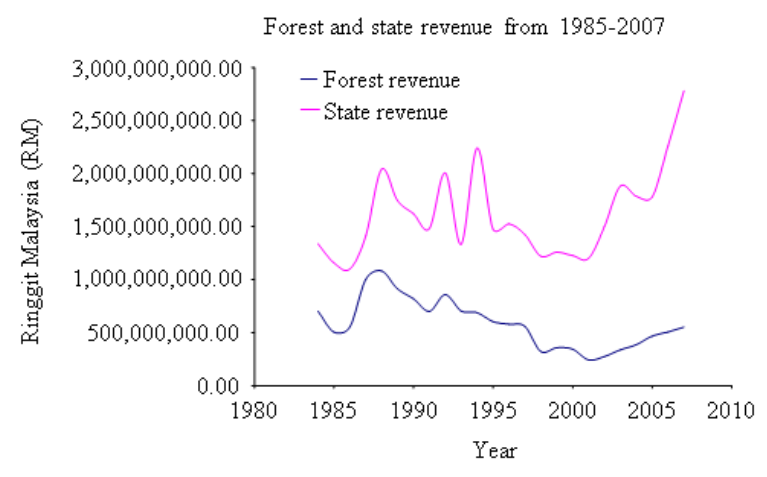

Fig. 1: Forest and state revenues (SFD)

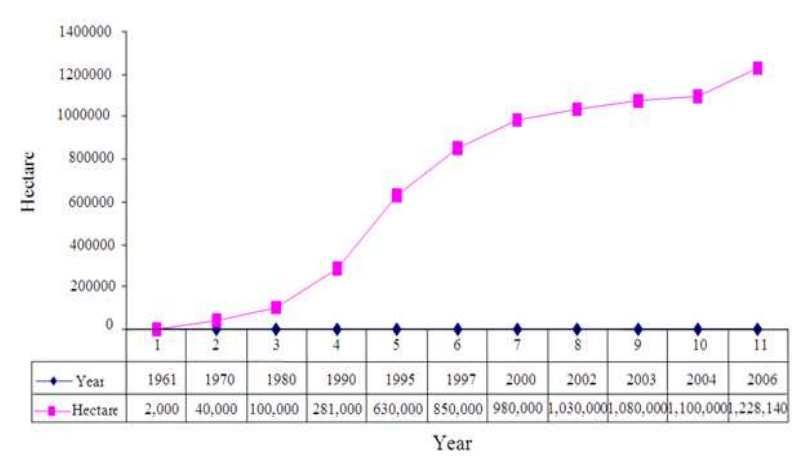

Fig. 2: Area of agricultural land planted with oil palm

expected that the annual forest revenue will drop to between RM50.0-RM100.0 million after 2012, when all logging operations wind up in Sabah, as the potential area to be logged will be very limited.

The key factors that contributed to the massive degradation and depletion of forests in Sabah include the unsustainable forest management practices, lack of silviculture and forest rehabilitation programme and the forest fires during the droughts session.

Palm oil plantation industry is another major contributor for Sabah revenues. In fact, in the 1980s, palm oil is the major export and industrial crop in the state, particularly in terms of the total cultivated land area, with a steady increase until 1990 and with rapid increase during the period 1990-2003 (Fig. 2). There was a general increase in Crude Palm Oil (CPO) export quantities until 1997, plunging to a very low level during the period 1997-2000 and surging from 20012004. The general increase in CPO export quantities is obviously related to the expansion of agricultural land cultivated with oil palm, coupled with an increasing demand for CPO in the international market. Demand for crude palm oil in the international market is increasing as the global community is trying to reduce the dependence on non-renewable fossil fuel.
Production of bio-fuel has provided new market for palm oil.

If the current trend continues, the production of $\mathrm{CPO}$ needs to be increased in order to meet such demand. In order to meet such demand, the pressure will be to develop additional land area for oil palm plantation, thus increasing the threats to the existing degraded forest areas.

The impacts of the reconditioning of the forests including the conversion of the degraded forest into large scale mono plantation (i.e., oil palm) have been enormous which lead to the following habitat ecological impacts that would affect the survival of orangutans, elephants and other wildlife in a long term period:

- Shrinking forests that brought wildlife especially large mammals like elephants into more frequent contact with people and thus increasing humanwildlife conflicts

- Fragmentation of the large mammals' population into several groups remains so isolated that they rarely or never meet to breed

- Limited high quality foods and a variety of fruits for wildlife especially for orangutan which is very much dependent on fruit trees for survival. In degraded forest and hill ranges where natural fruiting is infrequent and seasonal, orangutan populations may not be able to survive

Due to the current threats on the orangutan population as described above, WWF-Malaysia, under the Borneo Species Programme, seeks to promote a strategic solution, such as forest restoration program, in order to reduce the effects of the degraded forest on the flagship species especially the orangutans. This study aims to assess the technical, biological and financial challenges in planning and executing the forest restoration programme in order to support the conservation of the orangutan in North Ulu Segama, which could be used as lessons and guideline in the future.

The study area for this project is the Ulu Segama Malua (USM) Forest Reserves including the Danum Valley Conservation Area that supports over 5,300 orangutans, one of the highest density population area in Sabah. USM was first logged in 1960-1980, followed by the second logging activities in 1990-2000. The 3rd round of logging activities was carried out in year 2007 and ended in December 2007. A total of $75 \%$ of the forest in USM is a secondary forest and the forest quality is classified under stratum 3 (5-8 emergent tree $\left.\mathrm{ha}^{-1}\right)$ and stratum 4 (1-4 emergent tree $\left.\mathrm{ha}^{-1}\right)$. 


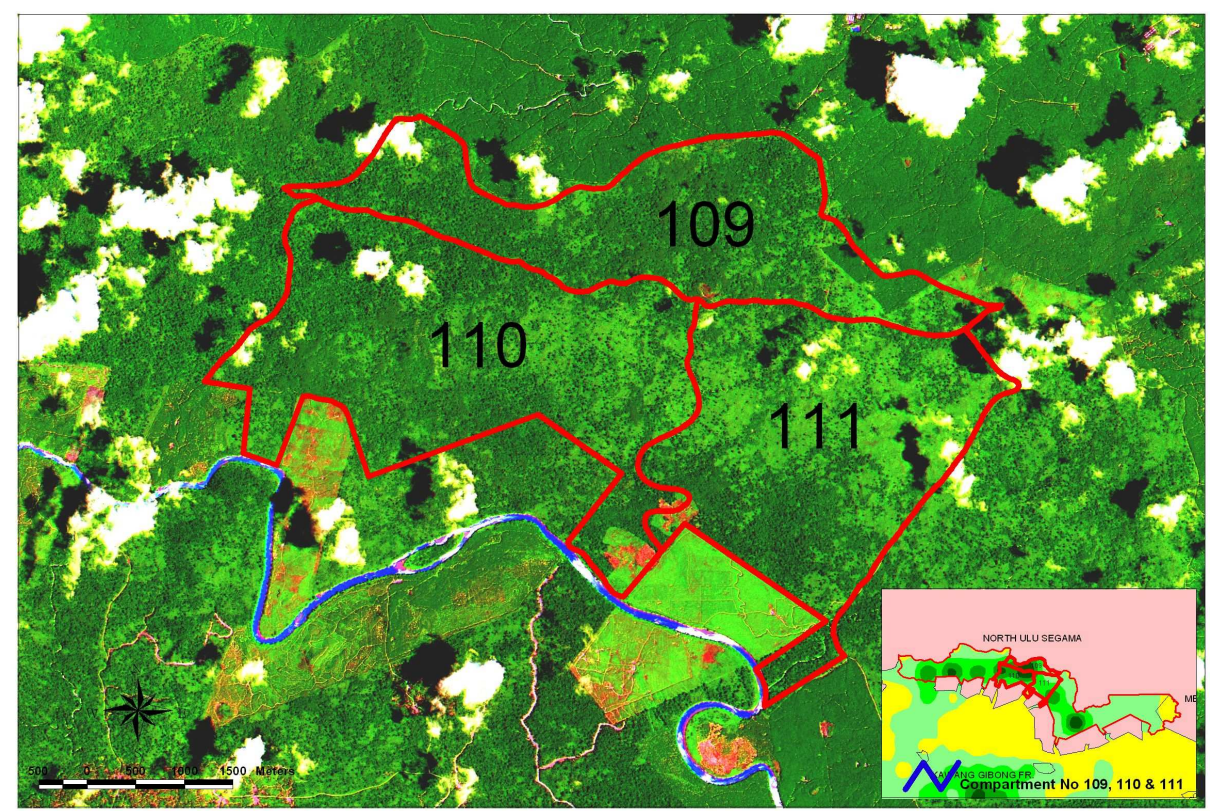

Fig. 3: Satellite imagery showing the location and forest condition in compartments No. 110,111, 112 at the heart of the NUS

The North Ulu Segama (NUS), which has a total area of 12,000 ha, is located at the northern part of USM Forest Reserve. A survey done by WWFMalaysia orangutan research team, which was carried out in October 2008, estimated that the orangutan population size in North Ulu Segama is approximately 300. The high density of orangutans in North Ulu Segama is caused by the influx of orangutans from the north, following the conversion of forest to oil palm plantations from year 1980-2000. Since orangutans are not able to swim and cannot survive in oil palm plantations, these orangutans are isolated from the main forest area by the Sigma River to the south and surrounded by the oil palm plantations on west, north and east sides. During prolonged periods of drought, these animals could have cut off from their main food sources and could die of starvation. This situation was aggravated by the fact that in 1997, about half of NUS forest area $(12,000 \mathrm{ha})$ was burned for the second time during the El Nino drought and has never been rehabilitated after the incident. The intensity of the burn varied from site to site, with natural vegetation almost eliminated at some sites, but only lightly damaged at others. The entire burned area remain dominated by shrubs, herbs, weedy climbing, plants and pioneer trees (e.g., Anthocephalus chinensis, Macaranga spp., Pterospermum spp., Merremia spp., Mikania spp., Caesalpinia spp., Zingiberaceae, Dinochloa spp.); original trees and remnants of the old growth forest canopy remain in scattered patches. Without active intervention through the burned areas including poor forest, the extensive secondary growth will remain, stunting and essentially halting the capacity for natural regeneration back to continuous, diverse tree canopy cover.

During the period of 2005-2007, based on the aerial survey combined with ground survey, the highest density of orangutans is located at the heart of the NUS (i.e., Compartment No. 109, 110 and 111). Although $40-60 \%$ of this area is already damaged from forest fire, the concentration of the orangutans in this area is very high and consistent due to the type of the soil in this area is very fertile (contain high mineral for plants and trees); as shown in the Fig. 3.

\section{MATERAILS AND METHODS}

Forest restoration planning methodology: In general, the main objective of forest restoration planned by Sabah Forestry Department is to improve timber productivity and restore the habitats for a diversity of flora and fauna. However, the forest landscape restoration programme inspired by WWF-Malaysia is designed to re-establish the presumed structure, productivity and species diversity of the forest originally present before and with high hopes that the ecological process and functions of the restored forest will match those of the original forest cover in time. 
Am. J. Environ. Sci., 6 (2): 137-151, 2010

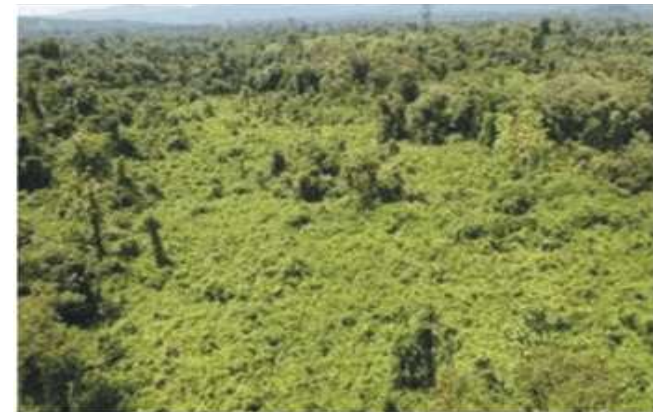

Fig. 4: Shrubby forests

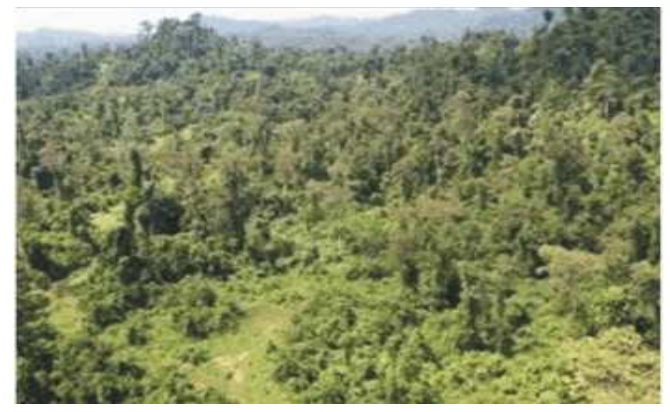

Fig. 5: Herbaceous vegetation

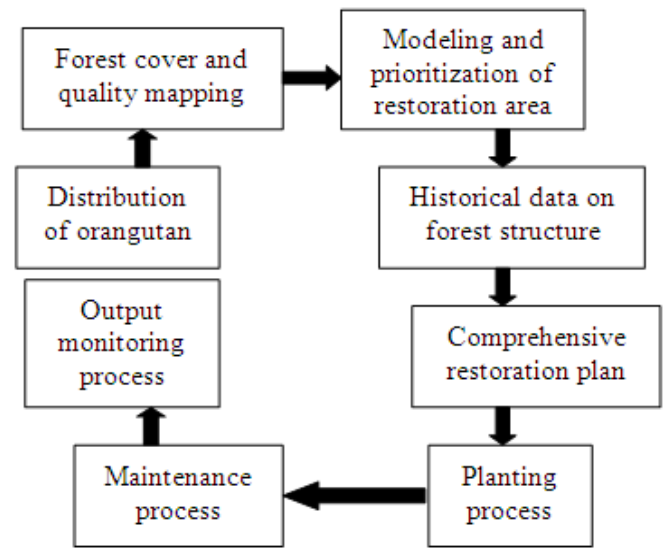

Fig. 6: Forest restoration planning and implementation process

The focus on forest restoration during this planning period will be organized within the prioritized areas that are located in the Natural Forest Management (NFM) area, conservation areas and degraded forest that are considered as a vital key habitat and ecological corridor for orangutans.

Most of the forest restoration effort focuses especially on those areas that are most degraded and classified as a very poor forest and secondary forests ('shrubby forests' and 'herbaceous vegetation' as shown in Fig. 4 and 5 respectively).
Table 1: GPS locations for 6 transect in NUS

\begin{tabular}{llll}
\hline Transect & X & Y & Distance (m) \\
\hline VH8 & $117^{\circ} 57^{\prime} 49.2^{\prime \prime}$ & $05^{\circ} 11^{\prime} 06.9^{\prime \prime}$ & 900 \\
VH10 & $117^{\circ} 59^{\prime} 18.8^{\prime \prime}$ & $05^{\circ} 10^{\prime} 43.5^{\prime \prime}$ & 900 \\
H2 & $118^{\circ} 00^{\prime} 05.9^{\prime \prime}$ & $05^{\circ} 10^{\prime} 36.6^{\prime \prime}$ & 900 \\
H1 & $118^{\circ} 00^{\prime} 48.3^{\prime \prime}$ & $05^{\circ} 10^{\prime} 26.9^{\prime \prime}$ & 900 \\
M10 & $118^{\circ} 00^{\prime} 46.7^{\prime \prime}$ & $05^{\circ} 09^{\prime} 30.3^{\prime \prime}$ & 900 \\
M3 & $118^{\circ} 00^{\prime} 40.8^{\prime \prime}$ & $05^{\circ} 09^{\prime} 02.3^{\prime \prime}$ & 900 \\
\hline
\end{tabular}

These areas are not expected to yield an economic cut and cannot function as a good biodiversity forest within one cutting cycle of 30-40 years if they are left to regenerate naturally. The overall forest restoration process is planned based on the following diagram (Fig. 6).

Distribution of orangutans: Aerial survey was carried out in order to gather the spatial distribution pattern of the orangutan population in Ulu Segama Malua FR. Aerial survey was carried out using a helicopter (Bell 206 Jet Ranger). We followed a systematic stratified sampling pattern using parallel line-transects, at $3 \mathrm{~km}$ interval spacing. Helicopter speed was maintained in between the range of 70-90 $\mathrm{kmh}^{-1}$ depending on the condition of the terrain elevation. Flying elevation varied from $70-80 \mathrm{~m}$ (depending on the terrain elevation) above the forest canopy. Sighting of orangutan nests is recorded using Garmin GPS map 76CSx, by two people who are sitting at the left and right back seat of the helicopter, while another person (co-pilot) sitting next to the helicopter pilot assisting the navigation part and taking photo on the forest condition.

After the aerial survey, the locations of the nests from the GPS handheld were downloaded directly using the Map Garmin software. The orangutan nest data is manipulated using the GIS software in order to develop the value of each grid. The value of the grid is actually generated based on aerial orangutan nest density index (orangutan's nest per $\mathrm{km}, \mathrm{n}^{\mathrm{a}} \mathrm{km}^{-1}$, where $\mathrm{n}^{\mathrm{a}}=$ number of orangutan's nest sighted and recorded during the aerial survey). Then, by using the value of each grid in the GIS system, surface interpolation method is used to model the nest density pattern in the study area.

Forest cover and quality mapping: Forest Assessment was carried out in North Ulu Segama. The purpose of this assessment is to assess the Potential Crop Tree (PCT) and the current Tree Stand and Stock (TSS). Forest assessment at North Ulu Segama (NUS) was carried out along six transects covering 3.0 ha sampling plot size. Table 1 shows the GPS location for each transect. 


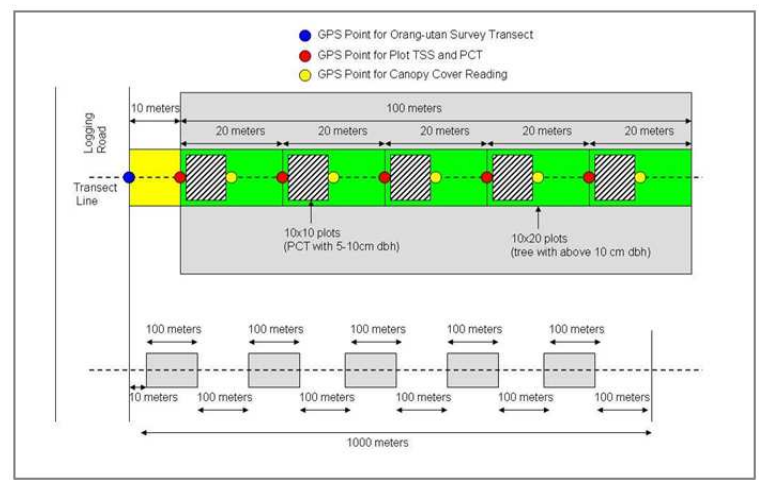

Fig. 7: Sampling plot for forest restoration

The location of the sampling plot is actually determined based on the satellite image interpretation (with resolution $2.5 \mathrm{~m}$ ), in order to ensure all type of vegetation is included in the sampling exercise. Each transect comprises five main sampling plots with the size $10 \times 100 \mathrm{~m}$ and each sampling plot is separated at a distance of $100 \mathrm{~m}$.

In each main sampling plot, five sub-sampling plots were developed with the size of $10 \times 20 \mathrm{~m}$. This sampling plot is used to collect data on trees (with diameter at breast-height (dbh), size above $10 \mathrm{~cm}$ ) in order to assess the status of "Tree Stand and Stock" (TSS).

The second sub-sampling plot was developed in each of the five sub-sampling plots with the size of $10 \times 10 \mathrm{~m}$ and data on tree species (less than $10 \mathrm{~cm}$ of $\mathrm{DBH})$ is recorded in order to get the status of the Potential Crop Tree (PCT) as shown in Fig. 7. Measurement of the "Diameter at the breast heightDBH" is normally measured by a measuring tape at a height of $1.3 \mathrm{~m}$. The size of the $\mathrm{DBH}$ and tree species is recorded.

The status of the trees were analyzed based on 6 categories of tree group, based on the size of the DBH, such as (i) $10-20 \mathrm{DBH}$, (ii) $20-30 \mathrm{DBH}$, (iii) $30-40$ $\mathrm{DBH}$, (iv) $40-50 \mathrm{DBH}$, (v) 50-60 DBH and (vi) more than $60 \mathrm{DBH}$.

Six transects were surveyed during the forest assessment activities in North Ulu Segama. About 150 sampling plots $(10 \times 20 \mathrm{~m}-0.02$ ha per plot $)$ were sampled for the "Tree Stand and Stock" assessment and 150 sampling plots $(10 \times 10 \mathrm{~m}-0.01$ ha per plot $)$ were used to record the existing tree species (below $10 \mathrm{~cm}$ of DBH) for the "Potential Tree Crop" assessment.

The canopy coverage of the tree is measured using the densitometer. Reading from the densitometer is recorded in four directions, namely North, South, East and West.
Modeling and prioritization of restoration: The identification of priority area for forest restoration programme will be based on the status of 5 parameters, which are the orangutan density pattern, the land capability classification, the terrain elevation, the forest type and status of the forest areas.

In addition to that, the forest condition status will be interpreted based on the number of trees of $>40 \mathrm{~cm}$ $\mathrm{DBH}$ that is interpreted from the crown size. The following notes describe the justification of the mentioned parameters to be used in the selection and prioritization process for the forest restoration programme.

Orangutans density pattern: It is very important to know where the key habitat for the orangutan having high density. Any forest restoration programme, initiated in the degraded forest with a high density of orangutan, will indirectly benefit the orangutan in a longer term.

Land capability classification: This parameter was included since some of the degraded forest lands are classified as a suitable area for agriculture development. Therefore, area that is still covered with degraded forest but suitable for agricultural development will have higher priority for forest restoration programme.

Terrain elevation: As mentioned earlier, the lowland (approximately below $400 \mathrm{~m}$ of terrain elevation) forests of Sabah are the most important habitat for orangutans and pygmy elephants, therefore this area will have higher priority for forest restoration.

Forest condition: Prioritization process will consider the forest that is classified as stratum no 4 and 5 to be restored since these forests condition will not be able to regenerate itself and may be converted into other land use.

Status of the forest areas: It is recommended to prioritize any forest area that is classified as conservation or protection forest area, since they will not be logged in the future.

Simple Additive Weighting (SAW) methods are the most often used techniques for tackling spatial multi-attribute decision making. The techniques are also referred to as "Weighted Linear Combination" (WLC) (Thomas and Luis, 2000). The decision rule evaluates each alternative, $A_{i}$, by the following formula:

$$
A_{i}=\sum w_{j} \times x_{i j}
$$


Where:

$A_{i}=$ Output Value that shows the status of forest area to be restored in certain size of sub-unit (normally in grid unit)

$\mathrm{x}_{\mathrm{ij}}=$ The score of the $\mathrm{i}^{\mathrm{th}}$ alternative with respect to the $\mathrm{j}^{\text {th }}$ attribute and weight

$\mathrm{w}_{\mathrm{i}}=\mathrm{A}$ normalized weight, so that $\sum \mathrm{w}_{\mathrm{i}}=1$

SAW method was used in selecting the priority areas because it provides a better and accurate projection of an area locality and it can analyze multiple data entries and also it is a proportional linear transformation of the raw data which means that the relative order of magnitude of the standardize scores remains equal.

It is also widely used in solving a real world problem due to its easiness; it can be implemented both in raster and vector GIS environment and operational zed using any GIS system having overlay capabilities or implemented in a spreadsheet environment (Rogers, 2001).

For USM Forest Reserves, using the spatial analyst, the relatively important layers namely (i) Orangutan density pattern; (ii) land capability classification; (iii) terrain elevation; (iv) forest type; (v) status of the forest areas, are run using the above equation and the priority area for forest restoration will be identified based on the higher grid value.

Historical data on forest structure: It is very important to gather the historical data on forest structure especially for those species that are consumed by the orangutan in the degraded forest. The data of the orangutan food tree species obtained from the previous researcher conducted the same study site is compiled. In this study, the orangutan research team has carried out the orangutan behavioral study for at least 18 months and all species of trees and plants that is consumed by the orangutan was recorded and compared with the data that is recorded by the previous researchers.

Comprehensive restoration plan: In order to identify a suitable forest restoration treatment and planting strategies, a series of consultation have been carried out with the government department, Sabah Forestry Department. A proper Comprehensive Restoration Plan (CRP) needs to be developed, before a suitable treatment and planting strategies could be determined. CRP is a database that is established during the site preparation work. During the site preparation in the forest restoration area, line clearing activities (including silviculture work) are carried out in the site. Planting point is marked on the ground, with the interval gap at least $8 \mathrm{~m}$ to each other. The forest canopy condition of the point is classified into three, namely (i) open canopy, (ii) semi canopy and (iii) closed canopy.

Standard Operation manual for forest restoration is jointly developed by WWF-Malaysia and Sabah Forestry Department. Site preparation, silviculture and tree planting are carried out by contractors, site inspection and verification is conducted by Sabah Forestry Department.

Monitoring the outputs: Forest restoration in North Ulu Segama was initiated in December 2007. The restoration programme consist of 4 times of maintenance activities which need to be implemented after two months the trees are planted and followed by maintenance every 23 months, depended on the ground condition.

Orangutan distribution in the study area is also spatially mapped in order to monitor the impact of the restoration activities on their movement. Aerial survey is carried out two times, i.e., (i) July-September 2007 and (ii) October 2008-November 2008.

\section{RESULTS}

Distribution of orangutans: Using the value of each grid in the GIS system, surface interpolation method is modeled to project the nest density pattern in the USM area, as shown in Fig. 8.

As shown in Fig. 8, five key areas were identified to have a very significant high density of orangutan, namely (i) Malua Forest Reserve area, (ii) North Ulu Segama area, (iii) Kawang Gibong Forest Reserve area, (iv) South part of Ulu Sungai Segama and (v) Western part of Ulu Sungai Danum (located at the west part of Danum Valley Conservation Area).

In this study, North Ulu Segama area is selected as a pilot project for the forest restoration for orangutan, since the area is isolated from other continuous forest landscape.

Forest cover and quality mapping: Generally, a total of 1,195 trees have been recorded comprising 145 species in 43 families. Based on the survey, the existing trees in the study area is dominated by Pterosternum elongatum (Bayor), Neolamarckia cadamba (Laran), Homalanthus populneus (Ludai Susu) with a percentage of composition at 13.56, 9.29 and 5.86\% respectively. Twenty main species that is recorded from the sampling plot is listed in Table 2 . 
Am. J. Environ. Sci., 6 (2): 137-151, 2010

Table 2: List of 20 most abundant species in NUS sampling plot

\begin{tabular}{lcc}
\hline Species & Total & Percent \\
\hline Pterospermum elongatum & 162 & 13.56 \\
Neolamarckia cadamba & 111 & 9.29 \\
Homalanthus populneus & 70 & 5.86 \\
Macaranga pearsonii & 57 & 4.77 \\
Pleiocarpadia sandakanica & 56 & 4.69 \\
Neonauclea gigantea & 38 & 3.18 \\
Glochidion rubrum & 32 & 2.68 \\
Croton argyratus & 26 & 2.18 \\
Brownlowea peltata & 23 & 1.92 \\
Clausena excavata & 21 & 1.76 \\
Paranephelium xestophyllum & 21 & 1.76 \\
Aglaia sp. & 20 & 1.67 \\
Pterocyambium javanicum & 20 & 1.67 \\
Ficus sp. & 19 & 1.59 \\
Neonauclea artocarpioides & 19 & 1.59 \\
Eugenia sp. & 17 & 1.42 \\
Fordia sp. & 17 & 1.42 \\
Meliosma pinnata & 16 & 1.34 \\
Trema orientalis & 16 & 1.34 \\
Cleistanthus myrianthus & 15 & 1.26 \\
\hline
\end{tabular}

Table 3: The list of prohibited and commercial trees at the sampling plot in NUS

\begin{tabular}{|c|c|c|}
\hline Prohibited trees & Commercial tr & \\
\hline$\overline{\text { Aquilaria malaccensis }}$ & Alstonia angustiloba & Myristica iners \\
\hline Baccaurea parviflora & Alstonia iwahigensis & Myristica sp. \\
\hline Baccaurea stipulate & Beilschmiedia sp. & Nauclea subdita \\
\hline Dracontomelon dao & Cananga odorata & Neoclea subdita \\
\hline Durio kutejensis & $\begin{array}{l}\text { Cratoxylum } \\
\text { Cochinchinense }\end{array}$ & $\begin{array}{l}\text { Nothaphoebe } \\
\text { obovata }\end{array}$ \\
\hline $\begin{array}{l}\text { Nephelium ramboutan } \\
\text { Ake }\end{array}$ & $\begin{array}{l}\text { Cryptocarya } \\
\text { griffithiana }\end{array}$ & Nothaphoebe sp. \\
\hline & Dehassia sp. & $\begin{array}{l}\text { Octomeles } \\
\text { sumatrana }\end{array}$ \\
\hline Shorea mecistopteryx & Dillenia borneensis & $\begin{array}{l}\text { Parashorea } \\
\text { malaanonan }\end{array}$ \\
\hline Sympetalandra & Dillenia excelsa & $\begin{array}{l}\text { Parashorea } \\
\text { tomentella }\end{array}$ \\
\hline broneensis & Duabanga moluccana & Pentace adenophora \\
\hline & Eugenia sp. & Pentace laxiflora \\
\hline & Knema laurina & Planchonia valida \\
\hline & Knema sp. & Polyalthia obliqua \\
\hline & Lithocarpus sp. & Polyalthia sp. \\
\hline & Litsea sessiliflora & $\begin{array}{l}\text { Pterocyambium } \\
\text { javanicum }\end{array}$ \\
\hline & Litsea $\mathrm{sp}$. & $\begin{array}{l}\text { Pterospermum } \\
\text { elongatum }\end{array}$ \\
\hline & Lophopetalum & Shorea gibbosa \\
\hline & $\begin{array}{l}\text { Macaranga } \\
\text { gigantea }\end{array}$ & Shorea parvifolia \\
\hline & $\begin{array}{l}\text { Macaranga } \\
\text { hypoleuca }\end{array}$ & Sindora irpicina \\
\hline & Macaranga pearsonii & Terminalia citrina \\
\hline & Magnolia condolii & Xanthophyllum affine \\
\hline & $\begin{array}{l}\text { Mesua macrantha } \\
\text { ellipticum }\end{array}$ & Xanthophyllum \\
\hline
\end{tabular}

Nine species of prohibited trees were recorded during the sampling plot exercise, while a total of 44 species are listed as a commercial timber and only one species recorded i.e., Chionanthus pluriflorus (Bangkulat) is found to be endemic to Borneo. The list of both prohibited and commercial trees are listed in Table 3.
Table 4: List of 20 most abundant tree family in NUS sampling plot

\begin{tabular}{lrc}
\hline Family & Total & Percent \\
\hline Euphorbiaceae & 287 & 24.02 \\
Rubiaceae & 247 & 20.67 \\
Sterculiaceae & 189 & 15.82 \\
Sapindaceae & 49 & 4.10 \\
Fabaceae & 47 & 3.93 \\
Tiliaceae & 37 & 3.10 \\
Meliaceae & 36 & 3.01 \\
Rutaceae & 29 & 2.43 \\
Moraceae & 22 & 1.84 \\
Sabiaceae & 18 & 1.51 \\
Ulmaceae & 17 & 1.42 \\
Myrtaceae & 17 & 1.42 \\
Dilleniaceae & 17 & 1.42 \\
Dipterocarpaceae & 16 & 1.34 \\
Lauraceae & 15 & 1.26 \\
Ebenaceae & 15 & 1.26 \\
Leeaceae & 11 & 0.92 \\
Combretaceae & 11 & 0.92 \\
Datiscaceae & 10 & 0.84 \\
Urticaceae & 9 & 0.75 \\
\hline
\end{tabular}

Table 5: List of most abundant species for TSS category

\begin{tabular}{lrc}
\hline Species & TSS & Percent \\
\hline Homalanthus populneus & 1 & 0.13 \\
Neolamarckia cadamba & 50 & 6.43 \\
Brownlowea peltata & 6 & 0.77 \\
Fordia sp. & 2 & 0.26 \\
Pterospermum elongatum & 148 & 19.02 \\
Pleiocarpadia sandakanica & 43 & 5.53 \\
Trema orientalis & 4 & 0.51 \\
Mallotus lackeyi & 0 & 0.00 \\
Cleistanthus myrianthus & 4 & 0.51 \\
Glochidion rubrum & 22 & 2.83 \\
Diospyros sp. & 5 & 0.64 \\
Dillenia borneensis & 3 & 0.39 \\
Leea indica & 1 & 0.13 \\
Paranephelium xestophyllum & 13 & 1.67 \\
Clausena excavata & 14 & 1.80 \\
Mallotus sp. & 1 & 0.13 \\
Aglaia sp. & 14 & 1.80 \\
Octomeles sumatrana & 5 & 0.64 \\
Macaranga pearsonii & 52 & 6.68 \\
Ficus sp. & 14 & 1.80 \\
\hline
\end{tabular}

The presence of Dipterocarpaceae in NUS area is relative low but on the other hand, Euphorbiaceous and Rubiaceae is dominating the area with more that $40 \%$ of the total trees are belongs to these two families. The percentage of 20 major families within NUS sampling plot is listed in Table 4.

Timber stock and stands: Under TSS category, a total of 778 trees have been recorded, consist of 122 species from 40 families. Bayor ( $P$. elongatum) represent $19 \%$ of the total tree at this category and follow by Macaranga pearsonii (Sedaman) with $6.68 \%$ and $N$. cadamba (Laran) with $6.43 \%$. Twenty main tree species recorded are provided in Table 5. 
Am. J. Environ. Sci., 6 (2): 137-151, 2010

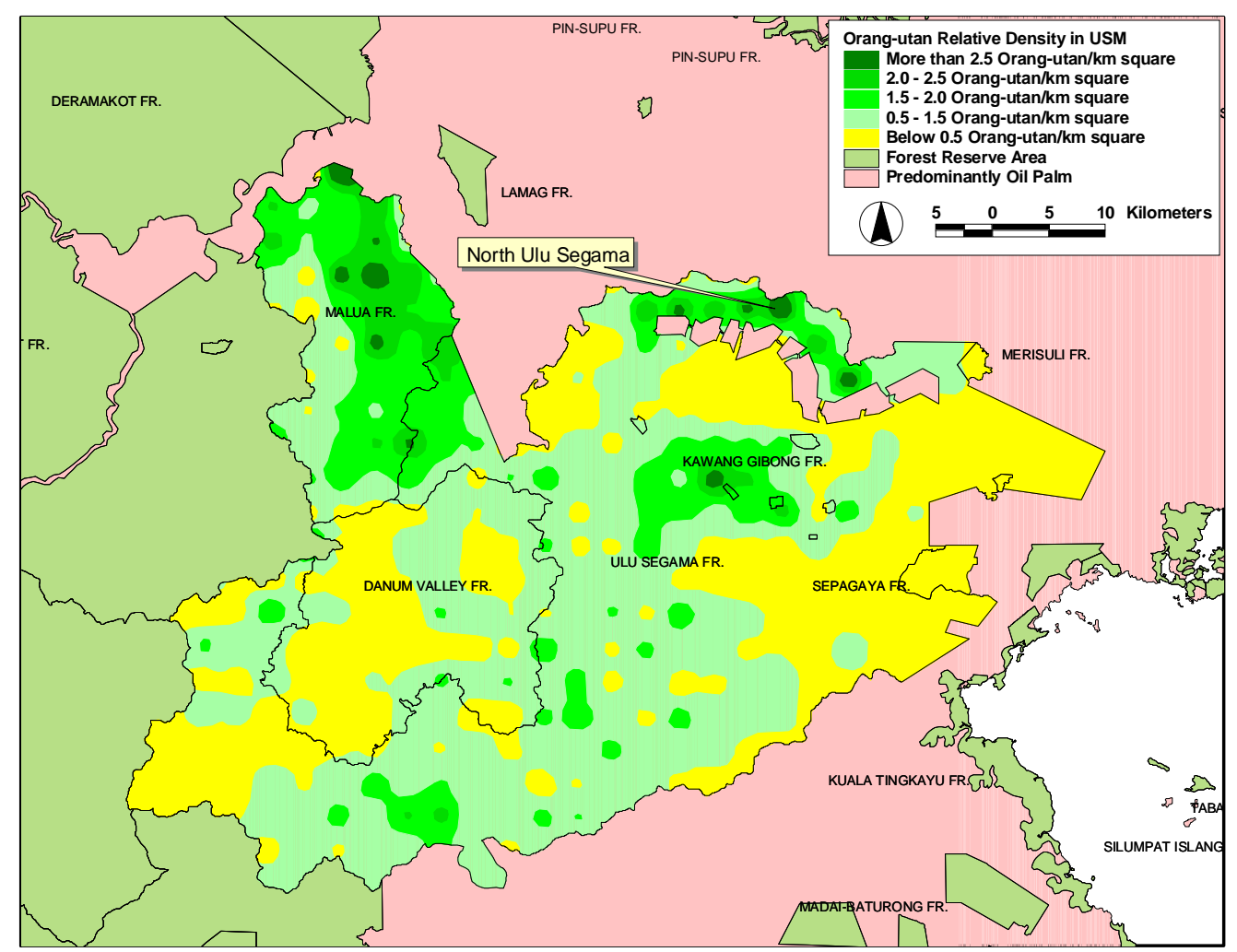

Fig. 8: Relative density of orangutan distribution in Ulu Segama Malua forest reserve

Table 6: List of ten main tree species in each class (based on dbh size in $\mathrm{cm}$ )

\begin{tabular}{|c|c|c|c|}
\hline dbh $10-20 \mathrm{~cm}$ & Percent & dbh $20-30 \mathrm{~cm}$ & Percent \\
\hline Pterospermum elongatum & 15.45 & Pterospermum elongatum & 20.53 \\
\hline Neolamarckia cadamba & 9.50 & Neonauclea gigantea & 10.60 \\
\hline Pleiocarpadia sandakanica & 8.51 & Macaranga pearsonii & 10.60 \\
\hline Glochidion rubrum & 3.76 & Croton argyratus & 5.96 \\
\hline Neonauclea artocarpioides & 3.56 & Meliosma pinnata & 3.97 \\
\hline Neonauclea gigantea & 3.37 & Saraca declinata & 3.97 \\
\hline Pterocyambium javanicum & 2.57 & Nenoauclea artocarpioides & 3.97 \\
\hline Paranephelium xestophyllum & 2.38 & Pterocyambium javanicum & 3.31 \\
\hline Clausena excavata & 2.38 & Eugenia sp. & 3.31 \\
\hline $\begin{array}{l}\text { Aglaia } \mathrm{sp} . \\
\text { dbh } 30-40 \mathrm{~cm}\end{array}$ & 2.38 & $\begin{array}{l}\text { Litsea } \mathrm{sp} . \\
\text { dbh } 40-50 \mathrm{~cm}\end{array}$ & 1.99 \\
\hline Pterospermum elongatum & 33.80 & Pterospermum elongatum & 33.33 \\
\hline Macaranga pearsonii & 26.76 & Macaranga pearsonii & 20.00 \\
\hline Croton argyratus & 4.23 & Macaranga hypoleuca & 16.67 \\
\hline Saraca declinata & 4.23 & Saraca declinata & 6.67 \\
\hline Neonauclea gigantea & 2.82 & Meliosma pinnata & 3.33 \\
\hline Meliosma pinnata & 2.82 & Melicope luna-akenda & 3.33 \\
\hline Melicope luna-akenda & 2.82 & Aglaia sp. & 3.33 \\
\hline Castanopsis sp. & 2.82 & Eugenia sp. & 3.33 \\
\hline Nenoauclea artocarpioides & 1.41 & Peltophorum racemosum & 3.33 \\
\hline Glochidion rubrum & 1.41 & Castanopsis motleyana & 3.33 \\
\hline $\begin{array}{l}\text { dbh } 50-60 \mathrm{~cm} \\
\text { Pterospermum elongatum }\end{array}$ & 14.29 & $\begin{array}{l}\text { Mature tree }(\mathrm{dbh}>60 \mathrm{~cm}) \\
\text { Pterospermum elongatum }\end{array}$ & 26.67 \\
\hline Macaranga pearsonii & 14.29 & Octomeles sumatrana & 13.33 \\
\hline Macaranga gigantea & 14.29 & Macaranga pearsonii & 6.67 \\
\hline Neolamarckia cadamba & 14.29 & Dimocarpus longan & 6.67 \\
\hline Alangium javanicum & 14.29 & Terminalia citrina & 6.67 \\
\hline Dimocarpus longan & 14.29 & Parashorea tomentella & 6.67 \\
\hline \multirow{4}{*}{ Pentace laxiflora } & 14.29 & Litsea sp. & 6.67 \\
\hline & & Barringtonia lanceolata & 6.67 \\
\hline & & Artocarpus anisophyllus & 6.67 \\
\hline & & Pometia pinnata & 6.67 \\
\hline
\end{tabular}


More than $60 \%$ of the recorded trees have the dbh size at $10-20 \mathrm{~cm}$ while only $15 \%$ of the trees has dbh more than $30 \mathrm{~cm}$. Mature tree (dbh more than $60 \mathrm{~cm}$ ) relatively very small, representing only $1.93 \%$ from the total trees (Fig. 9). P. elongatum is appeared to be dominating each dbh class, assessed in TSS category (Table 6).

With a sampling plot size at 3 ha for "Timber Stocks and Stands (TSS)" assessment, a total of 259 tree per ha are estimated present in NUS area.

For the "Potential Crop Timber (PCT)" assessment in a $1.5 \mathrm{ha}$, a total of 278 tree per ha are estimated present in the study area. For trees with dbh $30-60 \mathrm{~cm}$, approximately 36 trees stand per ha while only 5 mature trees $(\mathrm{dbh}$ more than $60 \mathrm{~cm}$ ) per ha are predicted remains at NUS. The comparison of density for each dbh class is shown in Fig. 10.

Potential Crop Tree (PCT): In PCT assessment, the total number of trees recorded is 471 trees comprising 87 species belong to 34 families. H. populneus is the main PCT's species recorded in the sampling plot with $16.55 \%$ from the total trees. N. cadamba tree species is found to be the second majority tree with the percentage at $14.63 \%$. The list of twenty main species of PCT category in NUS sampling plot are shown in Table 7.

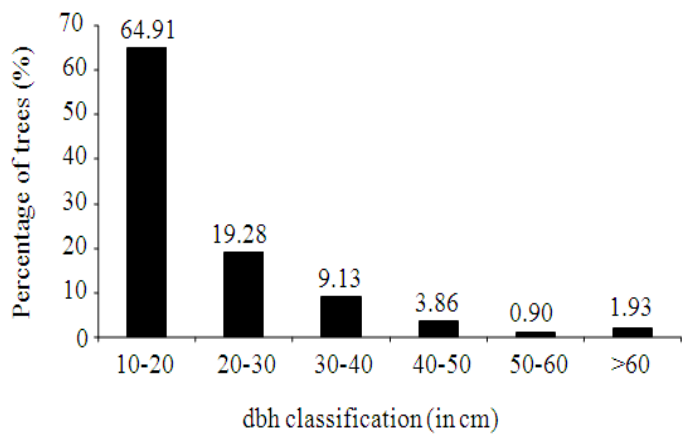

Fig. 9: Percentage of trees in each class (based on size of dbh), $\mathrm{n}=778$

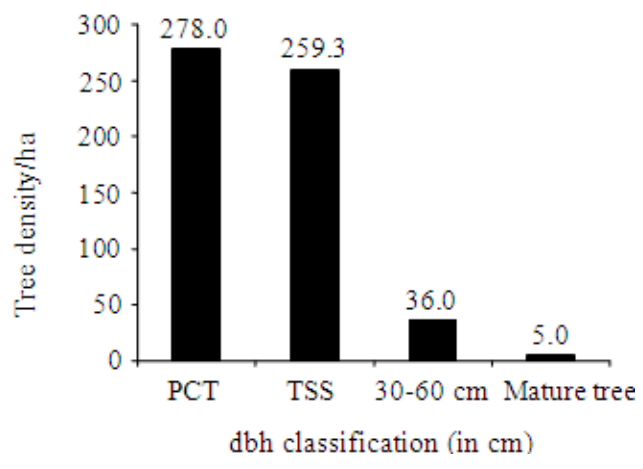

Fig. 10: Density of tree for each dbh category
Ten tree species with high density for each dbh class is presented in Table 8. Two species, H. populneus and $N$. cadamba are commonly found in the PCT category with estimation of more than 40 trees per ha. Bayor ( $P$. elongatum) dominating almost the tree density for TSS category with 49 trees per ha compared with other main species in this category such as $M$. pearsonii (17 trees/ha) and N. cadamba (16 trees per ha). However, tree density for trees with dbh at 30-60 cm and mature tree $(\mathrm{dbh}>60 \mathrm{~cm})$ generally low with less than 10 trees per ha for all species, as shown in Table 8.

Modeling and prioritization of restoration area: The total area for the priority forest to be restored in USM Forest Reserves is about 40,000 ha and the location of the priority area is highlighted in Fig. 11.

In USM, there are at least three main areas that is very important for forest restoration programme, namely (i) North Ulu Segama (approximately 9,000 ha), (ii) Malua Forest Reserve (approximately 29,000 ha) and (iii) Ulu Sungai Danum (approximately 2,000 ha).

Historical data on forest structure: MacKinnon (1974) had carried out the orangutan behavioral study in North Ulu Segama in 1975 which had recorded 97 species of food tress or plants. However, study from WWF-Malaysia in 2009 had recorded 71 species of food trees or plants in North Ulu Segama. About 26.8\% of the original food tree species that is consumed by the orangutans in year 1975 is not available anymore in year 2009 .

Comprehensive restoration plan: In NUS, WWFMalaysia's restoration area is located in Compartment no 109,110 and 111 . The restoration compartment then is divided into several blocks (with a minimum and maximum size area between 10.0-20.0 ha) as shown in Fig. 12.

Table 7: List of ten main tree species in PCT

\begin{tabular}{lcc}
\hline Species & Total & Percent \\
\hline Homalanthus populneus & 69 & 16.55 \\
Neolamarckia cadamba & 61 & 14.63 \\
Brownlowea peltata & 17 & 4.08 \\
Fordia sp. & 15 & 3.60 \\
Pterospermum elongatum & 14 & 3.36 \\
Pleiocarpadia sandakanica & 13 & 3.12 \\
Trema orientalis & 12 & 2.88 \\
Mallotus lackeyi & 12 & 2.88 \\
Cleistanthus myrianthus & 11 & 2.64 \\
Glochidion rubrum & 10 & 2.40 \\
Diospyros sp. & 10 & 2.40 \\
Dillenia borneensis & 10 & 2.40 \\
Leea indica & 10 & 2.40 \\
Paranephelium xestophyllum & 8 & 1.92 \\
Clausena excavata & 7 & 1.68 \\
Mallotus sp. & 7 & 1.68 \\
Aglaia sp. & 6 & 1.44 \\
Octomeles sumatrana & 6 & 1.44 \\
Macaranga pearsonii & 5 & 1.20 \\
Ficus sp. & 5 & 1.20 \\
\hline
\end{tabular}




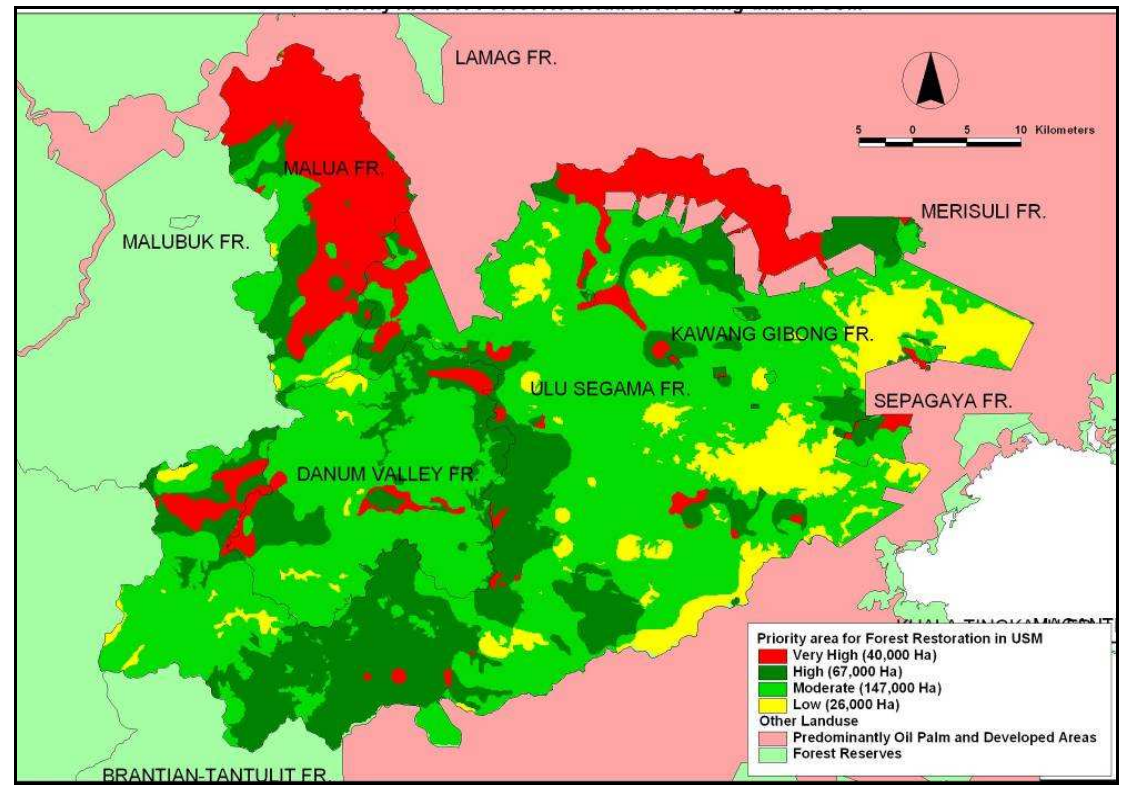

Fig. 11: Priority map for forest restoration programme for orangutan in Ulu Segama Malua FR

Table 8: The list of 10 species with high density for each dbh category

\begin{tabular}{|c|c|c|c|}
\hline Top PCT & tree $\mathrm{ha}^{-1}$ & Top TSS & tree ha $^{-1}$ \\
\hline $\begin{array}{l}\text { Homalanthus } \\
\text { Populneus }\end{array}$ & 46.0 & $\begin{array}{l}\text { Pterospermum } \\
\text { elongatum }\end{array}$ & 49.3 \\
\hline $\begin{array}{l}\text { Neolamarckia } \\
\text { Cadamba }\end{array}$ & 40.7 & $\begin{array}{l}\text { Macaranga } \\
\text { pearsonii }\end{array}$ & 17.3 \\
\hline $\begin{array}{l}\text { Brownlowea } \\
\text { Peltata }\end{array}$ & 11.3 & $\begin{array}{l}\text { Neolamarckia } \\
\text { cadamba }\end{array}$ & 16.7 \\
\hline Fordia sp. & 10.0 & $\begin{array}{l}\text { Pleiocarpadia } \\
\text { sandakanica }\end{array}$ & 14.3 \\
\hline $\begin{array}{l}\text { Pterospermum } \\
\text { Elongatum }\end{array}$ & 9.3 & $\begin{array}{l}\text { Neonauclea } \\
\text { gigantea }\end{array}$ & 11.7 \\
\hline $\begin{array}{l}\text { Pleiocarpadia } \\
\text { Sandakanica }\end{array}$ & 8.7 & $\begin{array}{l}\text { Croton } \\
\text { argyratus }\end{array}$ & 8.0 \\
\hline Mallotus lackeyi & 8.0 & $\begin{array}{l}\text { Glochidion } \\
\text { rubrum }\end{array}$ & 7.3 \\
\hline Trema orientalis & 8.0 & $\begin{array}{l}\text { Pterocyambium } \\
\text { javanicum }\end{array}$ & 6.0 \\
\hline $\begin{array}{l}\text { Cleistanthus } \\
\text { Myrianthus }\end{array}$ & 7.3 & $\begin{array}{l}\text { Neonauclea } \\
\text { artocarpioides }\end{array}$ & 6.0 \\
\hline $\begin{array}{l}\text { Dillenia } \\
\text { borneensis }\end{array}$ & 6.7 & $\begin{array}{l}\text { Clausena } \\
\text { excavata }\end{array}$ & 4.7 \\
\hline Top 30-60 cm & & Top $>60 \mathrm{~cm}$ & \\
\hline $\begin{array}{l}\text { Parashorea } \\
\text { Tomentella }\end{array}$ & 8.0 & $\begin{array}{l}\text { Shorea } \\
\text { johorensis }\end{array}$ & 3.0 \\
\hline $\begin{array}{l}\text { Pterospermum } \\
\text { Elongatum }\end{array}$ & 7.0 & $\begin{array}{l}\text { Pterospermum } \\
\text { elongatum }\end{array}$ & 2.0 \\
\hline $\begin{array}{l}\text { Dryobalanops } \\
\text { Lanceolata }\end{array}$ & 5.0 & $\begin{array}{l}\text { Parashorea } \\
\text { tomentella }\end{array}$ & 1.0 \\
\hline $\begin{array}{l}\text { Octomeles } \\
\text { Sumatrana }\end{array}$ & 4.0 & $\begin{array}{l}\text { Dendrocnide } \\
\text { elliptica }\end{array}$ & 1.0 \\
\hline $\begin{array}{l}\text { Ludikea } \\
\text { Borneensis }\end{array}$ & 3.0 & $\begin{array}{l}\text { Alangium } \\
\text { javanicum }\end{array}$ & 1.0 \\
\hline Diospyros sp. & 2.0 & $\begin{array}{l}\text { Barringtonia } \\
\text { lanceolata }\end{array}$ & 1.0 \\
\hline $\begin{array}{l}\text { Dipterocarpus } \\
\text { caudiferus }\end{array}$ & 2.0 & Pentace sp. & 1.0 \\
\hline Dehassia sp. & 2.0 & $\begin{array}{l}\text { Teijsmanniodendron } \\
\text { bogoriense }\end{array}$ & 1.0 \\
\hline Eugenia sp. & 2.0 & Shorealeprosula & 2.0 \\
\hline
\end{tabular}

The restoration treatment strategy for each of the restoration blocks is determined, based on the number of the points along the line clearing i.e., (i) open canopy, (ii) semi canopy and (iii) closed canopy.

Treatment strategy: As recommended by Sabah Forestry Department, restoration treatment may take two forms: Enrichment planting and intensive planting (Table 9).

The choice of species to be planted is largely fastgrowing indigenous trees of commercial value (within production/Natural Forest Management (NFM) area) and a mixture of indigenous trees and fruit trees in conservation areas. The species being considered are Laran (Neolamarckia cadamba), Binuang (Octomeles sumatrana), Magas (Duabanga moluccana), Ylang Ylang (Cananga odorata), Durian (Durio sp.), Ara (Ficus sp.), Bayur (Pterospermum sp.), Tongkol (Ficus sp.), Sengkuang (Dracontomelon costatum), Simpor (Ficus sp.), Bongkol (pioneer species) and Tarap (Artocarpus sp.). Depending on the availability of fund, the minimum expected annual rate of planting is ranged from 200-500 ha year ${ }^{-1}$.

Tree planting strategy: In the natural forest area (where the category of the forest is closed canopy), although no tree is planted, the existing trees in that particular area are recorded. However, dipterocarp trees species need to be planted when there is no dipterocarp tree available in the natural forest. In semi canopy and open canopy areas, dipterocarp trees and pioneer trees species were planted respectively. 
Am. J. Environ. Sci., 6 (2): 137-151, 2010

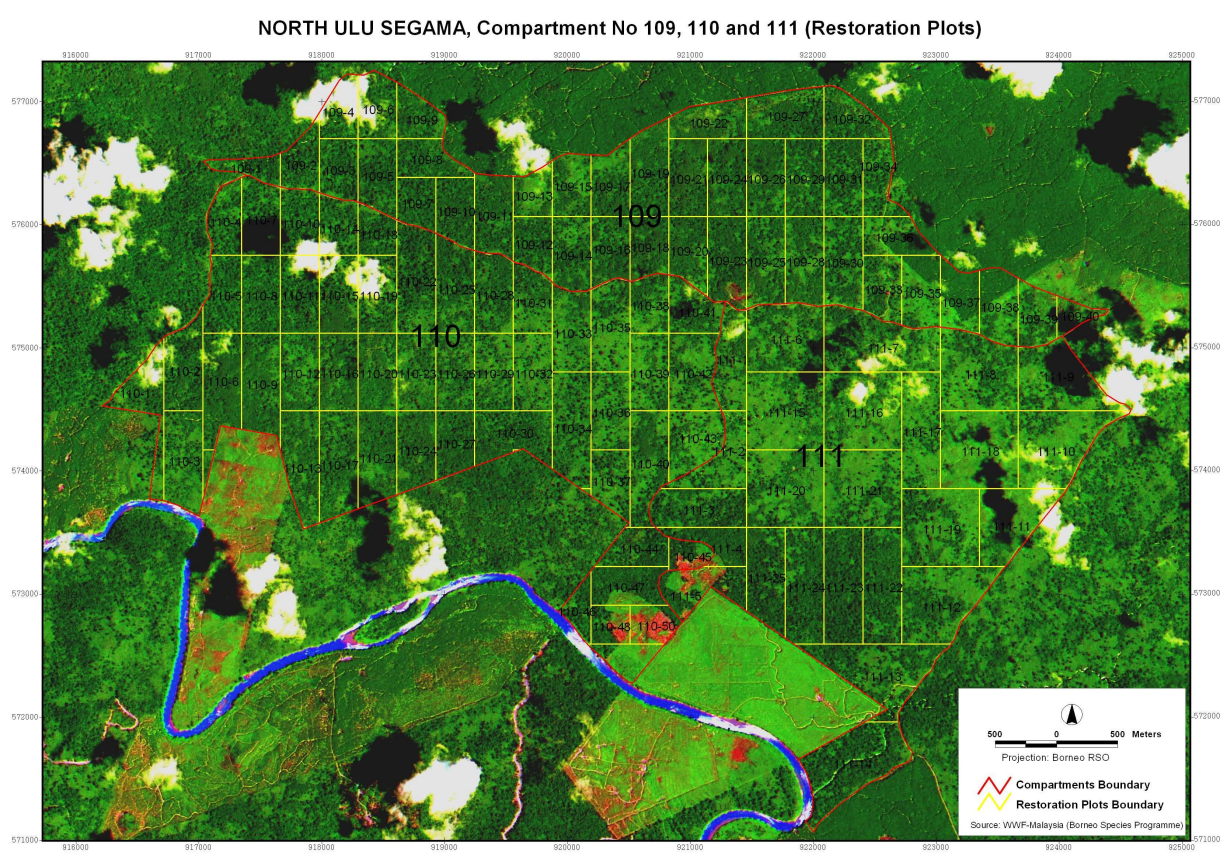

Fig. 12: North Ulu Segama's restoration plots

Table 9: Two forms of recommended forest restoration treatments to be carried out

\begin{tabular}{lll}
\hline Forest condition & Treatment & Description \\
$\begin{array}{l}\text { Vegetation covers dominated mainly } \\
\text { by shrubs or low tree cover of } \\
\text { little commercial value Fig. 3. }\end{array}$ & $\begin{array}{l}\text { Enrichment } \\
\text { planting }\end{array}$ & $\begin{array}{l}\text { Planting of seedlings } \\
\text { that can serve as a } \\
\text { food for orangutan and also seedlings } \\
\text { of commercially desirable species where their natural } \\
\text { regeneration has been determined to be poor. } \\
\text { Planting may be a mixture of both fast-growing } \\
(10-15 \text { year rotation) and slow-growing (15 year } \\
\text { rotation) species. Existing trees may be used as nurse } \\
\text { trees for those species that are not tolerant to open } \\
\text { conditions. Planting density is 150-200 planting points } \\
\text { per hectare. }\end{array}$ \\
& & $\begin{array}{l}\text { Planting of a mixture of fast-growing species with } \\
\text { rotation lengths between10-15 years. Canopy closure } \\
\text { can be expected in 3 yrs. Planting density is 300-350 } \\
\text { planting points per hectare. }\end{array}$ \\
\hline $\begin{array}{l}\text { Vegetation covers with scattered trees } \\
\text { and dominated by herbaceous growth, }\end{array}$ & $\begin{array}{l}\text { Intensive planting } \\
\text { such as, vines, grass and wild gingers }\end{array}$ & \\
Fig. 4. & &
\end{tabular}

Planting procedures adhered to the concept recommended by Sabah Forestry Department and WWF-Malaysia where in open canopy areas, Laran trees or Binuang trees were planted (Laran and Binuang trees are both the species consumed by orangutans). In the semi-canopy areas, the recommended dipterocarp species was planted. In the cluster point, at least 3 dipterocarp trees species were planted.

\section{Monitoring the outputs:}

Forest restoration programme: For the period of 24 months (December 2007-December 2009), the total area that was already planted is approximately 270 ha in compartment no 109 and the total dipterocarp and pioneer trees planted is about 35,000 trees (Table 10).

Based on the maintenance activities, the average survival rate for each block is shown in the histogram graph in Fig. 13, while the average survival rate for each round of maintenance is shown in the graph in Fig. 14.

The main reasons of the mortality are (i) trees were washed away by the water runoff from the river during flood season, (ii) trees were damaged by wild animals, (iii) unsuitable soil condition and (iv) unsuitable age of planted tree (due to the size (height) of the tree, roots of the tree were damaged during transporting and planting process). 
Am. J. Environ. Sci., 6 (2): 137-151, 2010

Table 10: List of trees planted in the restoration plots in the North Ulu Segama

\begin{tabular}{|c|c|c|c|}
\hline \multirow[b]{2}{*}{ Scientific name } & \multicolumn{3}{|l|}{ Fruit tree species } \\
\hline & Local name & Number & Sub-total \\
\hline Dimocarpus longan lour & Mata kucing & 292 & \\
\hline Baccaurea angulata merr. & Belimbing hutan & 110 & \\
\hline Durio spp. & Durian & 110 & \\
\hline Alangium javanicum (bl.) wangerin & Kondolon & 194 & 706 \\
\hline \multicolumn{4}{|l|}{ Pioneer Tree Species } \\
\hline Neolamarckia cadamba (roxb.) bosser & Laran & 5,099 & \\
\hline Octomeles sumatrana miq. & Binuang & 140 & \\
\hline Macaranga spp. & Macaranga & 0 & \\
\hline Pterospermum spp. & Bayur & 766 & 6,005 \\
\hline \multicolumn{4}{|l|}{ Dipterocarp Tree Species } \\
\hline Dyrobalanops lanceolata burck & Kapur paji & 7183 & \\
\hline Shorea leprosula miq. & Seraya tembaga & 2521 & \\
\hline Shorea fallax meijer & Seraya daun kasar & 606 & \\
\hline Shorea macrophylla(de vriese) ashton & Kawang jantung & 172 & \\
\hline Hopea nervosa king & Selangan jangkan & 8997 & \\
\hline Parashorea malaanonan (blanco) merr. & Urat mata daun licin & 1070 & \\
\hline Parashorea tomentella (sym.) meijer & Urat mata berudu & 1601 & \\
\hline Shorea argentifolia sym. & Seraya daun mas & 2420 & \\
\hline Shorea parvifolia dyer & Seraya punai & 1668 & \\
\hline Shorea ovalis (korth.) bl. & Seraya kepong & 697 & \\
\hline Shorea faguetoides ashton & Seraya kuning & 447 & \\
\hline Hopea ferruginea parijs & Selangan mata kucing & 455 & \\
\hline Shorea gibbosa brandis & Selangan kuning gajah & 197 & \\
\hline Dipterocarpus conformis van slooten & Keruing berudu kuning & 186 & 28,220 \\
\hline Total & & 34,931 & \\
\hline
\end{tabular}

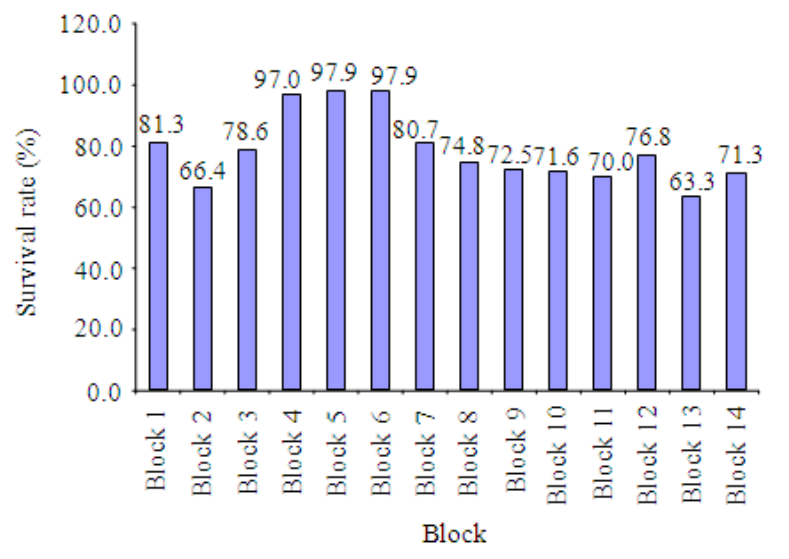

Fig. 13: Average survival rate for each block

Orangutan population: Table 11 shows the size of the study area (overall), number and length of linetransects, number of nest and corresponding effective strip width and nest detection index during the census of the NUS orangutan population.

Based on ground survey that was carried out during the first survey (July-September 2007) and the second survey (October-November 2008), a total of 264 orangutans was found during the first survey while a total of 449 orangutan was estimated during the second survey, as shown in Table 12.

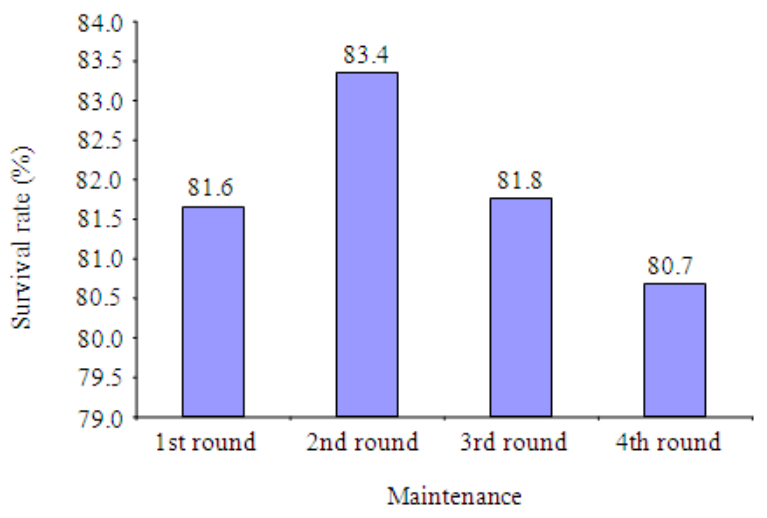

Fig. 14: Average survival rate for each round of maintenance

However, due to the forest condition in the NUS area which is not homogenous, the computation of the orangutan population estimation could be improved by processing the computation based on density zones. This process is normally called as stratification analyses.

Our survey consist of $11.44 \mathrm{~km}$ of total transect in the forest habitat with very high orangutan density, $7.49 \mathrm{~km}$ of total transect in the forest habitat with medium density of orangutan nest and $4.93 \mathrm{~km}$ of total transect in forest habitat with low density of orangutan nest, as described in the Table 13. 
Am. J. Environ. Sci., 6 (2): 137-151, 2010

Table 11: Sampling zone unit, number and length of line-transects number of nest and corresponding effective strip width and sampling effort

\begin{tabular}{|c|c|c|c|c|c|c|c|c|c|c|c|}
\hline \multicolumn{3}{|c|}{ Survey detail } & \multicolumn{6}{|l|}{ Transects } & \multicolumn{3}{|l|}{ Nests } \\
\hline Location & $\begin{array}{l}\text { Size } \\
\text { (ha) }\end{array}$ & $\begin{array}{l}\text { Duration } \\
\text { of survey }\end{array}$ & $\begin{array}{l}\text { Aerial nest } \\
\text { detection } \\
\text { index }\left(\mathrm{n}^{\mathrm{a}} \mathrm{km}^{-1}\right)\end{array}$ & $\begin{array}{l}\text { Number o } \\
\text { transects }\end{array}$ & $\begin{array}{l}\text { Average } \\
\text { f distance } \\
\text { (m) }\end{array}$ & $\begin{array}{l}\text { Min. } \\
(\mathrm{m})\end{array}$ & $\begin{array}{l}\text { Max. } \\
(\mathrm{m})\end{array}$ & $\begin{array}{l}\text { Total } \\
\text { length } \\
(\mathrm{m})\end{array}$ & Total & $\begin{array}{l}\text { Effective } \\
\text { strip width } \\
\text { (m) }\end{array}$ & Nest km ${ }^{-1}$ \\
\hline $\begin{array}{l}\text { North } \\
\text { Ulu } \\
\text { segama }\end{array}$ & 12.000 & $\begin{array}{l}\text { July-Sept. } \\
2007\end{array}$ & 17.93 & 35 & 492.3 & 70 & 1.000 & 17,230 & 216 & 19.01 & 12.54 \\
\hline $\begin{array}{l}\text { North } \\
\text { Ulu } \\
\text { segama }\end{array}$ & 12.000 & $\begin{array}{l}\text { Oct.-Nov. } \\
2008\end{array}$ & 34.58 & 33 & 722.9 & 70 & 1.000 & 23,856 & 316 & 15.05 & 13.25 \\
\hline
\end{tabular}

Table 12: Estimated number of orangutan density and population in north Ulu Segama based on density zoning

\begin{tabular}{|c|c|c|c|c|c|c|c|c|c|}
\hline \multicolumn{3}{|c|}{ Survey area } & \multicolumn{3}{|c|}{$\mathrm{D}$ (density) parameter } & \multicolumn{4}{|c|}{$\mathrm{N}$ (number) parameter } \\
\hline Area & $\begin{array}{l}\text { Size } \\
\text { (ha) }\end{array}$ & $\begin{array}{l}\text { Aerial } \\
\text { nest } \\
\text { index }\end{array}$ & $\begin{array}{l}\text { Point } \\
\text { estimate } \\
\text { (ind. } \mathrm{Km}^{-1} \text { ) }\end{array}$ & $\begin{array}{l}\text { Standard } \\
\text { error }\end{array}$ & $\begin{array}{l}\text { Percent } \\
\text { coef. of } \\
\text { variation }\end{array}$ & $\begin{array}{l}\text { Point } \\
\text { estimate } \\
\text { (no of ind.) }\end{array}$ & $\begin{array}{l}\text { Standard } \\
\text { error }\end{array}$ & $\begin{array}{l}\text { Percent } \\
\text { coef. of } \\
\text { variation }\end{array}$ & $\begin{array}{l}95 \% \text { confidence } \\
\text { interval }\end{array}$ \\
\hline$\overline{\text { NUS }}$ & 12.000 & 17.93 & 2.2 & $0.27655 \mathrm{E}-02$ & 12.59 & 264.0 & 33.24 & 12.59 & 205.0 \\
\hline NUS & 12.000 & 34.58 & 3.7 & $0.44313 \mathrm{E}-02$ & 11.85 & 449.0 & 53.22 & 11.85 & 353.0 \\
\hline
\end{tabular}

Table 13: Sampling zone unit, number and length of line-transects, number of nest and corresponding effective strip width and sampling effort

\begin{tabular}{|c|c|c|c|c|c|c|c|c|c|c|c|}
\hline \multirow[b]{2}{*}{$\begin{array}{l}\text { Zone/ } \\
\text { location }\end{array}$} & \multicolumn{3}{|c|}{ Sampling Zone Units (SZU) } & \multicolumn{5}{|l|}{ Transects } & \multicolumn{3}{|l|}{ Nests } \\
\hline & $\begin{array}{l}\text { Size } \\
\text { (ha) }\end{array}$ & $\begin{array}{l}\text { Duration } \\
\text { of survey }\end{array}$ & $\begin{array}{l}\text { Aerial nest } \\
\text { detection index }\end{array}$ & $\begin{array}{l}\text { Number of } \\
\text { transects }\end{array}$ & $\begin{array}{l}\text { Average } \\
\text { distance (m) }\end{array}$ & $\begin{array}{l}\text { Min. } \\
(\mathrm{m})\end{array}$ & $\begin{array}{l}\text { Max. } \\
(\mathrm{m})\end{array}$ & $\begin{array}{l}\text { Total } \\
\text { Length }(\mathrm{m})\end{array}$ & Total & $\begin{array}{l}\text { Effective } \\
\text { strip width (m) }\end{array}$ & Nest km ${ }^{-1}$ \\
\hline $\begin{array}{l}\text { Density } \\
\text { Zone } 1 \\
\text { located in } \\
\text { NUS }\end{array}$ & 4.466 & $\begin{array}{l}\text { Oct.-Nov. } \\
2008\end{array}$ & $\begin{array}{l}\text { Above } 40 \\
\text { nest km }{ }^{-1}\end{array}$ & 14 & 816.9 & 70 & 1.000 & 11.436 & 217 & 16.26 & 18.97 \\
\hline $\begin{array}{l}\text { Density } \\
\text { Zone } 2 \\
\text { located } \\
\text { in NUS }\end{array}$ & 3.227 & $\begin{array}{l}\text { Oct.-Nov. } \\
2008\end{array}$ & $\begin{array}{l}20-40 \\
\text { nest km }\end{array}$ & 9 & 832 & 700 & 1.000 & 7.490 & 73 & 12.76 & 9.75 \\
\hline $\begin{array}{l}\text { Density } \\
\text { zone } 3 \\
\text { located } \\
\text { in NUS }\end{array}$ & 4.307 & $\begin{array}{l}\text { Oct.-Nov. } \\
2008\end{array}$ & $\begin{array}{l}0-20 \\
\text { nest km }\end{array}$ & 10 & 493 & 250 & 1.000 & 4.930 & 26 & 14.76 & 5.27 \\
\hline
\end{tabular}

Table 14: Estimated number of orangutan density and population in North Ulu Segama based on density zoning

\begin{tabular}{|c|c|c|c|c|c|c|c|c|c|c|}
\hline \multicolumn{3}{|c|}{ Sampling Zone Units (SZU) } & \multicolumn{3}{|c|}{ D (density) parameter } & \multicolumn{5}{|c|}{$\mathrm{N}$ (number) parameter } \\
\hline Zone & $\begin{array}{l}\text { Size } \\
\text { (ha) }\end{array}$ & $\begin{array}{l}\text { Aerial nest } \\
\text { index }\end{array}$ & $\begin{array}{l}\text { Point estimate } \\
\text { (ind. } \mathrm{km}^{-2} \text { ) }\end{array}$ & $\begin{array}{l}\text { Standard } \\
\text { error }\end{array}$ & $\begin{array}{l}\text { Percent coef. } \\
\text { of variation }\end{array}$ & $\begin{array}{l}\text { Point estimate } \\
\text { (no of ind.) }\end{array}$ & $\begin{array}{l}\text { Standard } \\
\text { error }\end{array}$ & $\begin{array}{l}\text { Percent coef. } \\
\text { of variation }\end{array}$ & $\begin{array}{l}95 \% \text { co } \\
\text { interval }\end{array}$ & lence \\
\hline $\begin{array}{l}\text { Density } \\
\text { zone } 1\end{array}$ & 4.466 & $\begin{array}{l}\text { Above } 40 \\
\text { nest km }\end{array}$ & 3.9 & $\begin{array}{l}0.72216 \\
\text { E-02 }\end{array}$ & 18.58 & 174.0 & 32.33 & 18.58 & 117.0 & 257.0 \\
\hline $\begin{array}{l}\text { Density } \\
\text { zone } 2\end{array}$ & 3.227 & $\begin{array}{l}20-40 \\
\text { nest km }\end{array}$ & 2.5 & $\begin{array}{l}0.68828 \\
\text { E-02 }\end{array}$ & 27.04 & 82.0 & 22.17 & 27.04 & 45.0 & 149.0 \\
\hline $\begin{array}{l}\text { Density } \\
\text { zone } 3\end{array}$ & 4.307 & $\begin{array}{l}0-20 \\
\text { nest km }\end{array}$ & 1.1 & $\begin{array}{l}0.42707 \\
\text { E- } 02\end{array}$ & 35.88 & 51.0 & 18.30 & 36.30 & 25.0 & 104.0 \\
\hline
\end{tabular}

Based on the stratification computation, a total of 174 orangutans were estimated in zone 1 , while 82 and 51 orangutans were estimated in Zone 2 and Zone 3 respectively. Therefore, the total of estimated orangutan population living in the whole of North Ulu Segama is 307 (CI: 187-510) individuals. This estimation is based on separate analyses on line transects that were carried out in different density zone area, as shown in Table 14.

\section{DISCUSSION}

Prioritization of restoration area: Prioritization of the important degraded area to be restored is depended to the objective of the forest restoration. The process or modeling the priority area to be restored in this project is based on five parameter, namely (i) orangutan density pattern, (ii) land capability classification, (iii) terrain elevation, (iv) forest condition and (v) status of 
the forest areas. Each of the parameter is allocated with a certain weight as preferred by the programme. For this forest restoration programme, the priority area is identified based on the status of the orangutan in that particular area and therefore the North Ulu Segama are chosen as one of the key area for forest restoration programme.

However, in any other forest area or forest reserves, the priority area for forest restoration may focuses on different issues. The managers of the forest reserve may have different emphasize especially in selecting the priority area for restoration.

Mapping and monitoring of the orangutan population: The nest detection index either from the aerial or from the ground is increased during the second survey and therefore contributes to the increase of the orangutan population estimation in NUS. The number of orangutan in the second survey (Oct-Nov 2008, estimated n: 449 orangutan) increased (at 70\%), compared to the first survey (July-Sept 2007, n: 264 orangutan), which may due to the following factor:

- The orangutan behavior is disturbed during the period of (July-Sept 2007) which is due to the active logging activities in North Ulu Segama

- The destruction of the habitat due to the logging activities, affect the number of the nest that could be detected either from the aerial or during ground survey

The computation of the orangutan population using the standard procedure (assuming that forest habitat is equally homogeneous and orangutan distribution in the study area is distributed evenly), may resulting the population of the orangutan in North Ulu Segama to be over estimated.

However, if the survey data is analyzed separately based on the density zoning using stratification process (which is based on density pattern), the output of the survey is $\mathrm{n}$ : 307 . This is a more conservative approach in estimation orangutan number and population size due to the following assumption:

- Orangutan movement in the forest habitat is influenced by the "flowering season and fruiting pattern" of the tree species consist in the forest habitat

- Different tree species fruiting different season and density pattern of the orangutan in one habitat will be different from time to time
Assessing the forest quality and determining the treatment strategy: Forest quality assessment is a very important effort in order to determine the condition of the forest that need to be restored. In our forest assessment, we have selected several commercial dipterocarp tree species (that is recorded to be consumed by orangutan), to be planted in the restoration area since the area is identified to have a low density of this tree species.

Planting the tree species such as Bayor ( $P$. elongatum) is limited since most of the area in the restoration area is dominated by this species (4050 tree $\mathrm{ha}^{-1}$ ).

We also found that in NUS area, the tree density for trees with dbh at $30-60 \mathrm{~cm}$ is generally low less than 10 trees per ha for all species, while the status of mature tree $(\mathrm{dbh}>60 \mathrm{~cm})$ generally low with 5 trees $\mathrm{ha}^{-1}$. These information is very important as to (i) support decision making especially to determine the strategic treatment to be used in the forest restoration programme and, (ii) to justify the need of the forest restoration in this area as to secure the forest habitat for orangutans.

Implementation of the forest restoration programme: The underpinning threat of forest conversion stems from the economic argument that degraded forest cannot and do not generate revenue for the state government unless it is restored for which substantial funds and long period of time are needed, while other crops such as oil palm can generate revenue in 3 years time.

Two big challenges for the forest restoration programme in Sabah (based on this case study) in the future are (i) the availability of tree seedling especially the dipterocarp and other indigenous trees; (ii) Long term substantial funds are needed to implement forest restoration programme.

The supply for the dipterocarp seedling could be improved if the existing forest reserves (which still have good mother trees) could be managed sustainably. In order to ensure that tree seedlings are always adequate is to have the adjacent forest community to be involved in this forest restoration programme. The involvement by the forest communities in the project will not only help to ensure that the supply for the dipterocarp tree seedlings is adequate, but the programme will also indirectly create awareness among the forest communities the important of having a natural forest reserve as part of their source of income and also provide security for the forest reserve

In terms of financial need, so far, most of the funding for forest restoration is contributed either by private companies, international agencies or non- 
government agencies. The involvement of the local government in the forest restoration programme is not very encouraged. It is highly expected that forest restoration activities can bring back the value of the forest.

The relevant government authorities or the owners/managers of the forest reverse should emphasize to ensure that the financing mechanism in their Forest Management Plan, in order to support a long term forest restoration programme.

Long-term monitoring on the output of the restoration: Restoration commonly takes many years to achieve. Both involve succession processes that are unpredictable in their nature and the impacts of forest restoration on the wildlife (orangutan) are not always as expected. Thus long-term monitoring works on wildlife (orangutan) need to be continued to monitor their behavioral and ecology aspects. Besides, impacts on unpredictable el-nino during the restoration period are unknown.

\section{CONCLUSION}

The technical, biological and financial challenges in planning and executing the forest restoration programme in order to support the conservation of the orangutan in North Ulu Segama are presented in this study.

The project has identified the key challenges in implementation of the forest restoration. These challenges include:

- Identification of the priority area for forest restoration, which is depended on the objectives of the overall forest restoration programme

- Mapping the distribution of the orangutan may involve high cost, since this effort will include an aerial survey (helicopter survey) on orangutan's nest as well as ground survey. Orangutan's movement in the forest is very dynamic and hence an aerial survey is very important in order for us to be able to spatially map their distribution in the forest landscape. The cost will become higher if the area to be included in the forest restoration becomes higher

- Assessment of the forest quality will need the acquisition of a high resolution satellite images (at least $2.5 \mathrm{~m}$ resolution) in order to facilitate the forest sampling assessment on the ground. This assessment is very important as the output of the survey will be used to decide the suitable or potential tree that need to be planted in the restoration area
There are two key issues that need to be assessed and considered before forest restoration programme could be implemented, namely (i) the availability of tree seedling especially the dipterocarp and other indigenous trees; (ii) a long term substantial funds to support forest restoration programme.

A long term monitoring programme is important in order to monitor the successive of the forest restoration including monitoring the impact of the restoration upon the orangutan behavior as a result of adaptation to the new forest structure.

\section{ACKNOWLEDGEMENT}

We thank WWF-NL (including Adessium), WWFDE and WWF-UK (including Marks and Spencer) for their financial support to enable the orangutan survey status in Ulu Segama Malua especially in North Ulu Segama including financial support to initiate the Forest Restoration Programme in North Ulu Segama. We also would like to thanks the Director of Sabah Forestry Department (Datuk Sam Mannan) and support from Director of Sabah Wildlife Department (Mr. Laurentius Ambu), for granting us the permission to do the aerial survey in these two FMUsand also thank to all Borneo Species Programme's staffs (Mr. Middle Seen Kapis, Mr. Edwin Matulin, Mr. David James, Mr. William Joseph and Mr. Jabanus Miun) for their support in implementing the survey.

\section{REFERENCES}

MacKinnon, J.R., 1974. The Behavior and ecology of wild orangutans (Pongo pygmaeus). Anim. Behav., 22: 3-74.

Rogers, M., 2001. Engineering Project Appraisal: The Evaluation of Alternative Development Schemes. 1st Edn., Wiley-Blackwell, ISBN: 10: 0632056061, pp: 304.

Thomas, L.S. and G.V. Luis, 2000. Models, Methods, Concepts and Applications of the Analytic Hierarchy Process. Springer, ISBN: 0792372670. 